\title{
Management of the Black Mould Disease of Onion
}

Renu Gupta, MK Khokhar* and Ram Lal

Department of Plant Pathology, SKN College of Agriculture, RAU, Jobner - 303329, India

\begin{abstract}
Samples of onion seeds were collected from farmer's houses to manage the seed mycoflora of onion through fungicides, plant extracts and bioagent seed treatments. Amongst fungicides used as seed treatment, in vitro Bavistin (Carbendazim 50\% WP, 2.0\%) proved to be most effective against Aspergillus niger followed by Thiram ( $80 \%$ WP, 2.5\%), Captan (50\% WP, 2.5\%), Indofil M-45 (50\% WP, 2.5\%) and Topsin M (75\% WP, 2.5\%) in improving seed germination and vigour index, by reducing pre- and post emergence mortality and number of seedlings showing symptoms. Similarly, among bioagents and plant leaf extract used, Trichoderma viride $\left(5.0 \mathrm{ml}\left(10^{8} \mathrm{cfu} / \mathrm{ml}\right) / 10 \mathrm{~g}\right.$ seeds) followed by Trichoderma pseudokoningii $\left(5.0 \mathrm{ml}\left(10^{8} \mathrm{cfu} / \mathrm{ml}\right) / 10 \mathrm{~g}\right.$ seeds) and Safeda $(5.0 \mathrm{ml} / 10 \mathrm{~g}$ seeds $)$ followed by neem leaf extracts $(5.0 \mathrm{ml} / 10 \mathrm{~g}$ seeds) proved to be effective in improving seed germination and vigour index, by reducing pre- and post emergence mortality and number of seedlings showing symptoms.
\end{abstract}

Keywords: Management; Onion; Black mould; Fungicides

\section{Introduction}

Onion [Allium cepa (L.)] vernacularly called 'Pyaz' in Hindi and locally known as 'Kanda', is one of the most important vegetable cum condiment crop of family Alliaceae, grown in over all the parts of India. Onion is used throughout the year in the form of salad or condiment or for cooking with other vegetables. Onion has several medicinal uses, its use in the case of sun strokes is known worldwide [1]. Pests and diseases continue to impact on the productivity of crops and quality of crop products worldwide despite many years of research and development on improved methods for their control. It has been estimated that an average of $0.20-0.30$ of crop yield is lost annually from the field [2]. Black mould disease caused by Aspergillus niger van Tieghem (An) is a limiting factor in onion (Allium cepa L.) production worldwide [3]. Aspergillus niger also primary reported to survive between onion crops as a soil saphrophyte (on decaying organic matter) in or on onion bulbs or on cull onions in field or storage and being ubiquitous in occurrence, it attacks/infect bulbs of onion in field/storage, whenever they find injured tissues by producing various enzymes or toxins [4]. Association of A. niger with onion seeds produced in hot (desert) climates and their transmission from soil and naturally contaminated seeds to onion seedlings and sets, have also been reported by [5] and causes 30 to $80 \%$ loss/spoilage of onion bulb. Seed treatment with different biocides (bioagents and plant leaf extracts) has been reported to be safest in comparison to fungicides. Several biocides have been reported to increase seed germination and vigour index by reducing the pre- and post emergence mortality in several crops including onion [6,7]. In the present investigation an attempt was made to evaluate fungicides, plant extracts and bioagents against Black mould disease of onion.

\section{Material and Methods}

Apparently healthy surface sterilized seeds of onion were collected from farmer's houses, artificially inoculated with pathogenic A. niger and treated (dressing/soaking) separately by

\section{Fungicides}

\begin{tabular}{|c|c|c|c|}
\hline S.No. & Fungicides & Chemical Name & Dose \\
\hline & Bavistin & $\begin{array}{l}\text { Methyl Benzimidazole } \\
\text { carbamate }\end{array}$ & Bavistin@2.0 g/kg \\
\hline
\end{tabular}

\begin{tabular}{|l|l|l|l|}
\hline 2. & Captan & $\begin{array}{l}\text { N-trichloromethyl } \\
\text { thio-4-cyclohexane-1,2 } \\
\text { dicarboximide }\end{array}$ & Captan @2.5 g/kg \\
\hline 3. & Indofil M-45 & $\begin{array}{l}\text { Manganese-ethylene bis- IndofilM-45 @2.5 g/ } \\
\text { dithiocarbamate } \\
\text { kg }\end{array}$ \\
\hline 4. & Thiram & $\begin{array}{l}\text { Tetra methylthiuram dis- Thiram @2.5 g/kg } \\
\text { ulphide }\end{array}$ \\
\hline 5. & Topsin M & $\begin{array}{l}\text { Tetrachloro-1, 3, benezene- TopsinM @2.5 g/kg } \\
\text { dicarbonitrate }\end{array}$ \\
\hline
\end{tabular}

\section{Plant leaf extracts ${ }^{*}$}

\begin{tabular}{|l|l|l|l|}
\hline S.No. & $\begin{array}{l}\text { Plant leaf } \\
\text { extracts }\end{array}$ & Botanical Name & Concentration \\
\hline 1 & Datura & Datura stramonium & $@ 5.0 \mathrm{ml} / 10 \mathrm{~g}$ seeds \\
\hline 2 & Mahandi & Lawsonia inermis & $@ 5.0 \mathrm{ml} / 10 \mathrm{~g} \mathrm{seeds}$ \\
\hline 3 & Neem & Azardirachta indica & $@ 5.0 \mathrm{ml} / 10 \mathrm{~g} \mathrm{seeds}$ \\
\hline 4 & Safeda & Eucalyptus terticornis & $@ 5.0 \mathrm{ml} / 10 \mathrm{~g}$ seeds \\
\hline 5 & Tulsi & Ocimum sanctum & $@ 5.0 \mathrm{ml} / 10 \mathrm{~g}$ seeds \\
\hline
\end{tabular}

${ }^{\star}$ Leaf extracts of each plant leaves were prepared separately by washing the leaves, chopping and grinding them in a pestle and mortar with the addition of cold water in room temperature at the ratio of 1:2 (1 part of leaf:2 parts of water). The extracts were squeezed through cotton wool and used immediately [8]. Seed were soaked for 30 minutes, dried in shade for 2 hours before plating [6].

\section{Bioagents}

\begin{tabular}{|l|l|l|}
\hline S.No. & Bioagents & Dose \\
\hline (i) & Bacillus pumulis & $@ 5.0 \mathrm{ml}\left(10^{8} \mathrm{cfu} / \mathrm{ml}\right) / 10$ gm seeds \\
\hline (ii) & Pseudomonas fluorescens & $@ 5.0 \mathrm{ml}\left(10^{8} \mathrm{cfu} / \mathrm{ml}\right) / 10$ gm seeds \\
\hline (iii) & Trichoderma harzianum & $@ 5.0 \mathrm{ml}\left(10^{8} \mathrm{cfu} / \mathrm{ml}\right) / 10$ gm seeds \\
\hline (iv) & T. pseudokoningii & $@ 5.0 \mathrm{ml}\left(10^{8} \mathrm{cfu} / \mathrm{ml}\right) / 10$ gm seeds \\
\hline (v) & T. viride & $@ 5.0 \mathrm{ml}\left(10^{8} \mathrm{cfu} / \mathrm{ml}\right) / 10$ gm seeds \\
\hline
\end{tabular}

*Corresponding author: MK Khokhar, Department of Plant Pathology, SKN College of Agriculture, RAU, Jobner - 303329, India, E-mail: khokharmk3@gmail.com

Received August 20, 2012; Accepted September 17, 2012; Published September 20, 2012

Citation: Gupta R, Khokhar MK, Lal R (2012) Management of the Black Mould Disease of Onion. J Plant Pathol Microb 3:133. doi:10.4172/2157-7471.1000133

Copyright: ( 2012 Gupta R, et al. This is an open-access article distributed under the terms of the Creative Commons Attribution License, which permits unrestricted use, distribution, and reproduction in any medium, provided the original author and source are credited. 
Citation: Gupta R, Khokhar MK, Lal R (2012) Management of the Black Mould Disease of Onion. J Plant Pathol Microb 3:133. doi:10.4172/21577471.1000133

Page 2 of 3

\begin{tabular}{|c|c|c|c|c|c|c|c|c|}
\hline \multirow[t]{2}{*}{ S.No. } & \multirow[t]{2}{*}{ Treatments } & \multirow[t]{2}{*}{ Dose (\%) } & \multirow{2}{*}{$\begin{array}{c}\text { Percent } \\
\text { germination }\end{array}$} & \multicolumn{2}{|c|}{ Percent mortality } & \multirow{2}{*}{$\begin{array}{l}\text { Root* }^{*} \\
\text { length } \\
\text { (cm) }\end{array}$} & \multirow{2}{*}{$\begin{array}{l}\text { Shoot* length } \\
\text { (cm) }\end{array}$} & \multirow[t]{2}{*}{ Vigour index } \\
\hline & & & & Pre-emergence & Post- emergence & & & \\
\hline \multirow[t]{2}{*}{1.} & Bavistin & 2.0 & 75.00 & 2.25 & 2.50 & 6.00 & 6.25 & 918.75 \\
\hline & & & $(60.00)$ & $(8.53)$ & $(9.10)$ & & & \\
\hline \multirow[t]{2}{*}{2.} & Captan & 2.5 & 68.00 & 3.00 & 3.75 & 4.00 & 4.25 & 561.00 \\
\hline & & & $(55.55)$ & $(9.98)$ & $(11.09)$ & & & \\
\hline \multirow[t]{2}{*}{3.} & Indofil M-45 & 2.5 & 64.50 & 3.75 & 4.50 & 3.50 & 3.00 & 419.25 \\
\hline & & & $(53.43)$ & (11.09) & (12.25) & & & \\
\hline \multirow[t]{2}{*}{4.} & Thiram & 2.5 & 72.00 & 2.75 & 2.95 & 5.25 & 4.50 & 702.00 \\
\hline & & & $(58.05)$ & $(9.46)$ & $(9.81)$ & & & \\
\hline \multirow[t]{2}{*}{5.} & Topsin M & 2.5 & 62.00 & 4.00 & 5.75 & 3.00 & 2.10 & 316.20 \\
\hline & & & $(51.94)$ & $(11.83)$ & $(13.81)$ & & & \\
\hline \multirow[t]{2}{*}{6.} & Control & - & 61.00 & 14.00 & 12.00 & 2.75 & 1.95 & 286.70 \\
\hline & & & $(51.35)$ & $(21.97)$ & $(20.27)$ & & & \\
\hline \multicolumn{2}{|c|}{ S.Em \pm} & & 1.08 & 0.21 & 0.23 & - & - & 10.45 \\
\hline \multicolumn{2}{|c|}{ C.D. at $5 \%$} & & 3.19 & 0.63 & 0.69 & - & - & 30.95 \\
\hline
\end{tabular}

*Average based on 10 seedlings

Figures given in parentheses are angular transformed value

Table 1: Effect of fungicide seed treatment against Aspergillus niger on seed germination, pre-and post emergence mortality and vigour index (in vitro).

\begin{tabular}{|c|c|c|c|c|c|c|c|}
\hline \multirow[t]{2}{*}{ S.No. } & \multirow[t]{2}{*}{ Treatments } & \multirow{2}{*}{$\begin{array}{c}\text { Percent } \\
\text { germination }\end{array}$} & \multicolumn{2}{|c|}{ Percent mortality } & \multirow[t]{2}{*}{ Root* length $(\mathrm{cm})$} & \multirow{2}{*}{$\begin{array}{l}\text { Shoot* length } \\
\text { (cm) }\end{array}$} & \multirow[t]{2}{*}{ Vigour index } \\
\hline & & & $\begin{array}{c}\text { Pre - } \\
\text { emergence }\end{array}$ & $\begin{array}{c}\text { Post - } \\
\text { emergence }\end{array}$ & & & \\
\hline \multirow[t]{2}{*}{1.} & Datura (Datura stramonium) & 65.00 & 8.25 & 8.75 & 3.75 & 4.00 & 503.75 \\
\hline & & $(53.73)$ & $(16.64)$ & $(17.16)$ & & & \\
\hline \multirow[t]{2}{*}{2.} & Mahandi (Lawsonia inermis) & 61.75 & 8.75 & 9.00 & 3.00 & 2.25 & 324.18 \\
\hline & & $(51.77)$ & $(17.16)$ & $(16.43)$ & & & \\
\hline \multirow[t]{2}{*}{3.} & Neem (Azadirachta indica) & 70.25 & 6.50 & 6.75 & 4.95 & 5.25 & 716.55 \\
\hline & & $(56.91)$ & $(14.77)$ & $(15.00)$ & & & \\
\hline \multirow[t]{2}{*}{4.} & Safeda (Eucalyptus terticornis) & 73.00 & 5.75 & 6.00 & 5.25 & 6.00 & 821.25 \\
\hline & & $(58.82)$ & $(19.81)$ & $(14.18)$ & & & \\
\hline \multirow[t]{2}{*}{5.} & Tulsi (Ocimum sanctum) & 67.00 & 7.00 & 8.00 & 4.25 & 5.00 & 619.75 \\
\hline & & $(54.94)$ & $(15.34)$ & $(16.43)$ & & & \\
\hline \multirow[t]{2}{*}{6.} & Control & 61.00 & 12.00 & 14.00 & 2.50 & 2.00 & 274.50 \\
\hline & & $(51.35)$ & (20.27) & (18.44) & & & \\
\hline \multicolumn{2}{|c|}{$\begin{array}{r}\text { S.Em } \pm \\
\end{array}$} & 1.01 & 0.31 & 0.35 & - & - & 9.63 \\
\hline \multicolumn{2}{|r|}{ C.D. at $5 \%$} & 3.00 & 0.93 & 1.05 & - & - & 28.54 \\
\hline
\end{tabular}

${ }^{*}$ Average based on 10 seedlings

Figures given in parentheses are angular transformed values

Table 2: Effect of plant leaf extract seed treatment against Aspergillus niger on seed germination, pre- and post emergence mortality and vigour index (in vitro).

Inoculated untreated seeds were used as control. Twenty seeds were placed at an equal distance in each Petri dish. These Petri dishes were incubated at $22 \pm 1^{\circ} \mathrm{C}$ with 12 hours of light alternating with 12 hours of dark period. Observations were recorded after 15 days instead of 7 days on seed germination, pre- and post emergence mortality and root/shoot length. Seedling vigour was also calculated by formula given by Abdul-Baki and Anderson [9].

Vigour index $=$ Germination \% $\mathrm{x}($ Root length + Shoot length $)$

\section{Results and Discussion}

In this study all the seed dressing fungicides tested, Bavistin and Thiram were found to be most effective against $A$. niger but Bavistin gave highest percentage of seed germination and minimum pre-and post-emergence mortality with less number of seedlings showing symptoms followed by Thiram, Captan, Indofil M-45, Topsin M for the control of $A$. niger (Table 1). Bavistin has already been reported to be the best seed dresser against seed- borne A. niger of onion by Gupta et al. [10] and Singh et al. [11].
The seeds soaked in different plant leaf extracts, Safeda leaf extract followed by Neem leaf extract found to be most effective against seed borne $A$. niger in improving seed germination and vigour index by reducing pre- and post emergence mortality and number of seedling showing symptoms (Table 2). Extract of different parts of plants also reported to be effective in inhibiting the growth of $A$. niger (causing fruit rot in chilli and damping off in brinjal) by Bagri et al. [12] and Jacob and Sivaprakasam [9].

Seed treatment with the antagonists reported to be the cheapest method of delivery of antagonists to the rhizosphere of crop plants that are to be protected from seed and soil borne diseases [13]. Seed treatment with different bioagent such as Trichoderma viride followed by Trichoderma pseudokoningii was found to be most effective against seed borne $A$. niger in improving seed germination and vigour index by reducing pre- and post emergence mortality and number of seedling showing symptoms (Table 3). Seed treatment with Bacillus subtilis, Chaetomium globsum, Gliocladium virens, Pseudomonas fluorescens, Ralstonia fluorescens, Trichoderma hamatum, T. harzianum, T. 
Citation: Gupta R, Khokhar MK, Lal R (2012) Management of the Black Mould Disease of Onion. J Plant Pathol Microb 3:133. doi:10.4172/21577471.1000133

Page 3 of 3

\begin{tabular}{|c|c|c|c|c|c|c|c|}
\hline \multirow[t]{2}{*}{ S. No. } & \multirow[t]{2}{*}{ Treatments } & \multirow{2}{*}{$\begin{array}{c}\text { Percent } \\
\text { germination }\end{array}$} & \multicolumn{2}{|c|}{ Percent mortality } & \multirow[t]{2}{*}{ Root* length (cm) } & \multirow[t]{2}{*}{ Shoot* length $(\mathrm{cm})$} & \multirow[t]{2}{*}{ Vigour index } \\
\hline & & & $\begin{array}{c}\text { Pre - } \\
\text { emergence }\end{array}$ & $\begin{array}{c}\text { Post - } \\
\text { emergence }\end{array}$ & & & \\
\hline \multirow[t]{2}{*}{1.} & $\begin{array}{l}\text { Trichoderma } \\
\text { viride }\end{array}$ & 71.00 & 6.60 & 7.00 & 4.00 & 5.75 & 692.25 \\
\hline & & $(57.42)$ & (14.89) & $(15.34)$ & & & \\
\hline \multirow[t]{2}{*}{2.} & $\begin{array}{l}\text { Trichoderma } \\
\text { harzianum }\end{array}$ & 65.25 & 7.00 & 8.25 & 3.75 & 4.25 & 522.00 \\
\hline & & $(53.85)$ & $(15.34)$ & (16.64) & & & \\
\hline \multirow[t]{2}{*}{3.} & $\begin{array}{l}\text { Trichoderma } \\
\text { pseudokoningii }\end{array}$ & 67.00 & 6.75 & 8.00 & 3.85 & 5.00 & 592.95 \\
\hline & & $(54.94)$ & $(15.00)$ & $(16.43)$ & & & \\
\hline \multirow[t]{2}{*}{4.} & $\begin{array}{l}\text { Pseudomonas } \\
\text { fluorescens }\end{array}$ & 63.00 & 7.50 & 9.25 & 3.50 & 4.00 & 472.50 \\
\hline & & $(52.53)$ & (15.89) & $(17.66)$ & & & \\
\hline \multirow[t]{2}{*}{5.} & Bacillus pumulis & 62.00 & 8.25 & 10.00 & 3.00 & 2.00 & 310.00 \\
\hline & & (51.35) & (16.64) & $(18.44)$ & & & \\
\hline \multirow[t]{2}{*}{6.} & Control & 60.00 & 15.00 & 13.00 & 2.50 & 1.95 & 267.00 \\
\hline & & $(50.77)$ & (22.79) & $(21.13)$ & & & \\
\hline \multicolumn{2}{|l|}{ S.Em+ } & 1.04 & 0.31 & 0.34 & - & - & 8.61 \\
\hline \multicolumn{2}{|c|}{ C.D. at $5 \%$} & 3.09 & 0.92 & 1.00 & - & - & 25.50 \\
\hline
\end{tabular}

${ }^{*}$ Average days on 10 seedlings

Figures given in parentheses are angular transformed values

Table 3: Effect of bioagent seed treatment against Aspergillus niger on seed germination, pre- and post-emergence mortality and vigour index (in vitro).

koningii, T. virens and T. viride have been reported to give good control of associated pathogenic fungi with tomato, brinjal, chilli, blackgram and sesamum seeds, respectively [14-16]. In present investigation, we observed that seed treatment with different fungicides, increased germination percentage and vigour index on one hand and reduced pre-and post-emergence mortality and the number of seedlings showing symptom on the other.

\section{Acknowledgement}

The authors would like to thank the Head, Department of Plant Pathology and Dean, SKN college of Agriculture, Jobner, Jaipur for providing necessary facilities.

\section{References}

1. Rai N, Yadav DS (2005) Ch. 2.2 Onion. Ad in veg prod. Research Book Centre, Delhi.

2. Oerke EC (2006) Crop losses to pests. Journal of Agricultural Science 144: $31-43$

3. Ozer N, Koycu ND (2004) Seed-borne fungal diseases of onion and their control. Academic Publishers, Dordrecht.

4. Srinivasan R, Shanmugam V (2006) Post-harvest management of black mould rot of onion. Indian Phytopathol 59.

5. Hayden NJ, Maude RB (1992) The role of seedborne Aspergillus niger in transmission of black mould of onion. Plant Pathol 41: 573-581.

6. Jacob CK, Sivaprakasam K (1994) Evaluation of some plant extracts antagonists for the control of pre-emergence damping off brinjal (Solanum melongena L.) Chapter - 37 in Crop Disease-Innovative Techniques and Management. Kalyani Publishers, New Delhi.

7. Kaur NP, Mukhopadhyay AN (1992) Integrated control of 'chickpea wilt complex' by Trichoderma and chemical methods in India. Tropical Pest Management 38 : 372-375.

8. Alice D (1984) Studies on antifungal properties of some plant extracts. Agricultural University, Coimbatore.

9. Abdul-Baki AA, Anderson JD (1973) Vigour determination of soybean seed by multiple criteria. Crop Sci 13.

10. Gupta RP, Mehra U, Pandey UB (1989) Effects of various chemicals on viability of onion seed in storage. Seed Res 17: 99-101.
11. Singh BK, Singh CP, Katiyar RP (1996) Effect of various fungicides on viability of onion (Allium cepa) seed in storage. Seed Res 24: 61-63.

12. Bagri RK, Choudhary SL, Rai PK (2004) Management of fruit rot of chilli with different plant products. Indian Phytopathol 57.

13. Sivaprakasam K, Seetharaman K (1994) Crop diseases innovative techniques and management. (1stedn), Kalayani Publishers, New Delhi.

14. Pandey KK, Pandey PK (2005) Differential response of biocontrol agents against soil pathogens on tomato, chilli and brinjal. Indian Phytopathol 58.

15. Babu S, Seetharaman K, Nandakumar R, Johnson I (2000) Efficacy of fungal antagonists against leaf blight of tomato caused by Alternaria solani (Ell. and Mart.). Journal of Biological Control 14: 79-81.

16. Pathania N, Chandel SS, Singh SP (2004) Screening of bio-control agents discoloured (dirty black and brown) Colletotrichum capsici causing anthracose of bell paper. Seed Res Co 32: 111-112. 